\title{
Sistem Penyediaan Air Bersih Desa Metatu dan Desa Kalipadang Kecamatan Benjeng Kabupaten Gresik
}

\author{
Anisa Nanhidayah dan Alfan Purnomo \\ Departemen Teknik Lingkungan, Fakultas Teknik Sipil dan Perencanaan, Institut Teknologi Sepuluh Nopember (ITS) \\ e-mail: alfan_p@enviro.its.ac.id
}

\begin{abstract}
Abstrak-Penelitian ini dilatarbelakangi oleh minimnya akses pelayanan PDAM dan HIPPAM pada tahun 2015 di Kecamatan Benjeng yaitu 0,7 \% untuk pelayanan SPAM PDAM dan 5,95 \% pelayanan SPAM HIPPAM. Penelitian ini bertujuan inventarisasi sumber air bersih untuk keperluan penyediaan air bersih, memetakan wilayah dan menganalisis upaya pemenuhan kebutuhan air bersih sebagai solusi dalam penanganan masalah ketersediaan air bersih yang masih terbatas, dan memberikan rekomendasi penerapan teknologi pengolahan air yang cocok untuk Kecamatan Benjeng. Hasil penelitian ini adalah inventarisasi sistem penyediaan air bersih di mana masyarakat di Kecamatan Benjeng, khususnya Desa Metatu dan Desa Kalipadang memanfaatkan air sumber yang berasal dari air embung dan air tanah (sumur). Desa Metatu memiliki sistem penyediaan air yang lebih bagus dibandingkan sistem penyediaan di Desa Kalipadang, dikarenakan sumber air di Desa Metatu mampu memenuhi kebutuhan air penduduknya. Desa Metatu memiliki kuantitas embung yang cukup besar sehingga lebih cocok diterapkan teknologi pengolahan air embung. Sedangkan Desa Kalipang lebih cocok diterapkan teknologi pengolahan air sumur sederhana bagi masyarakat yang memiliki sumur, sedangkan masyarakat yang tidak memiliki sumur, diterapkan teknologi hidran umum dikarenakan letak desa berdekatan dengan jalur distribusi PDAM.
\end{abstract}

Kata Kunci-Air Bersih, Inventarisasi, Kecamatan Benjeng, Teknologi Air.

\section{PENDAHULUAN}

$\mathrm{P}$ ENYEDIAAN air bersih untuk masyarakat mempunyai peranan yang sangat penting dalam meningkatkan kesehatan lingkungan atau masyarakat, yakni berperan dalam menurunkan angka penderita penyakit, khususnya yang berhubungan dengan air, dan berperan dalam meningkatkan standar atau taraf/kualitas hidup masyarakat [1].

Penyelenggaraan pelayanan prasarana dan sarana lingkungan pemukiman, termasuk diantaranya adalah penyediaan air bersih menjadi tugas dan tanggung jawab Pemerintah Kabupaten/Kota, sesuai dengan UU No. 23 Tahun 2014 yang mengatur tentang Pemerintah Daerah. Penyediaan dan pemenuhan kebutuhan air bersih dapat dilakukan dengan sistem perpipaan maupun sistem non perpipaan tergantung dari sumber air baku, sarana, dan prasarana di wilayah tersebut. Sistem perpipaan dikelola oleh Perusahaan Daerah Air Minum (PDAM) dan sistem non perpipaan dikelola oleh masyarakat baik secara individu maupun secara kelompok.

Dikaitkan dengan lokasi studi kasus, hampir sepertiga bagian dari wilayah Kabupaten Gresik merupakan daerah pesisir pantai. Meskipun Kecamatan Benjeng tidak berbatasan langsung dengan laut, namun sebagian wilayah sumber airnya bersifat payau. Dalam pemenuhan kebutuhan air bersih sebagian besar masyarakat masih mengandalkan sumur yang bergantung pada musim. Hal tersebut menyebabkan sumur di Kecamatan Benjeng tidak cukup memadai untuk digunakan kebutuhan sehari-hari. Berdasarkan Statistik Daerah Kecamatan Benjeng 2016 [2] diketahui bahwa jumlah penduduk Kecamatan Benjeng sebesar 64.221 jiwa dengan luas wilayah 6.126 ha, namun tingkat pelayanan PDAM dan HIPPAM di Kecamatan Benjeng berdasarkan buku RISPAM Gresik [3] tertuang pada Tabel 1.

Tabel 1

Tingkat Pelayanan PDAM dan HIPPAM Tahun 2015

\begin{tabular}{cccc}
\hline \hline Kecamatan & $\%$ & $\begin{array}{c}\% \\
\text { PDAM }\end{array}$ & $\begin{array}{c}\text { Total } \% \\
\text { Pelayanan }\end{array}$ \\
\hline Kebomas & 91,8 & 0,69 & 92,5 \\
Gresik & 73,0 & - & 73,0 \\
Manyar & 62,9 & 10,67 & 73,6 \\
Duduk sampean & 25,6 & 3,36 & 29,0 \\
Kedamean & 2,6 & 2,14 & 4,7 \\
Menganti & 50,3 & 0,87 & 51,2 \\
Cerme & 71,1 & 3,24 & 74,3 \\
Benjeng & 0,7 & 5,95 & 6,6 \\
Balongpanggang & - & 8,34 & 8,3 \\
Driyorejo & 91,4 & 3,16 & 94,6 \\
Wringin Anom & 0,7 & 6,03 & 6,7 \\
Panceng & - & 27,25 & 27,3 \\
Ujung Pangkah & - & 5,13 & 5,1 \\
Sidayu & - & 0,69 & 0,7 \\
Dukun & - & 34,56 & 34,6 \\
Bungan & - & 12,37 & - \\
Tambak & - & - & 41,4 \\
Sangkapura & $-9,46$ & -4 \\
Jumlah & - & & - \\
\hline \hline
\end{tabular}

Sumber: BAPPEDA Gresik, 2015

\section{METODE PENELITIAN}

Penelitian ini dilakukan dalam skala lapangan. Teknik pengumpulan data dilakukan dengan mengambil data sekunder seperti: key map, RISPAM Gresik Tahun 2015, dan jumlah penduduk desa pada instansi terkait. Selain itu, dilakukan observasi langsung di lapangan atas sarana dan prasarana air bersih perdesaan dengan diambil titik koordinat lokasi menggunakan GPS dan didokumentasikan, wawancara 
dengan perangkat desa setempat dan warga pengguna air bersih, serta pengambilan sampel air di titik sumber air yang digunakan oleh warga.

Tabel 2.

Indikator penilaian Sistem Penyediaan Eksisting Indikator Kuantitas

\begin{tabular}{ccll}
\hline Bobot (A) & \multicolumn{2}{c}{ Skor (B) } & Nilai (C) \\
\hline Indikator & - jika kuantitas kecil & \\
kuantitas & diberi skor 1 & \\
diberi bobot & $\begin{array}{l}\text { - jika kuantitas sedang } \\
\text { diberi skor 3 }\end{array}$ & C = A x B \\
40 & $\begin{array}{l}\text { jika kuantitas besar } \\
\text { diberi skor 5 }\end{array}$ & \\
\hline
\end{tabular}
Batasan

- kuantitas kecil jika volume $<25.000 \mathrm{~m}^{3}$

- kuantitas sedang berada antara $25.000 \mathrm{~m}^{3}-50.000 \mathrm{~m}^{3}$

- kuantitas besar jika volume $>50.000 \mathrm{~m}^{3}$

- kuantitas sumur dianggap sedang untuk sumur gali, besar untuk sumur bor berdasarkan hasil survei terhadap responden. Sedangkan kuantitas debit dari PDAM menurut hasil survei juga mencukupi, sehingga masuk kategori kuantitas besar

\begin{tabular}{ccll}
\hline \multicolumn{4}{c}{ Indikator Kualitas } \\
\hline Bobot (D) & \multicolumn{2}{c}{ Skor (E) } & Nilai (F) \\
\hline Indikator & - jika kualitas & buruk & \\
kualitas diberi & diberi skor 1 & \\
bobot 20 & $\begin{array}{l}\text { jika kualitas } \\
\text { diberi skor 3 }\end{array}$ & sedang & F = D x E \\
& $-\begin{array}{l}\text { jika kualitas bagus } \\
\text { diberi skor 5 }\end{array}$ & \\
& &
\end{tabular}

Nama Dusun

\begin{tabular}{l} 
Batasan \\
\hline - kualitas jelek menunjukkan hasil uji melebihi nilai baku \\
mutu \\
- kualitas sedang menunjukkan hasil uji mendekati nilai \\
baku mutu \\
- kualitas bagus menunjukkan hasil uji lebih kecil \\
(mendekati 0) dari nilai baku mutu
\end{tabular}

\begin{tabular}{|c|c|c|}
\hline \multicolumn{3}{|c|}{ Indikator Kontinuitas } \\
\hline Bobot (G) & Skor $(\mathrm{H})$ & Nilai (I) \\
\hline $\begin{array}{c}\text { Indikator } \\
\text { kontinuitas } \\
\text { diberi bobot } \\
40 \\
\end{array}$ & $\begin{array}{l}\text { - jika tidak kontinu } \\
\text { diberi skor } 1 \\
\text { - jika kontinu diberi } \\
\text { skor } 5\end{array}$ & $\mathrm{I}=\mathrm{G} \times \mathrm{H}$ \\
\hline & Batasan & \\
\hline
\end{tabular}

- tidak kontinu menandakan sumber air tidak mencukupi kebutuhan masyarakat selama musim kemarau (6 bulan)

- kontinu menandakan sumber air mencukupi kebutuhan masyarakat selama musim kemarau ( 6 bulan)

- Untuk kontinuitas sumur dalam dianggap kontinu berdasarkan hasil survei terhadap responden. Sedangkan kontinuitas dari PDAM menurut hasil survei juga kontinu selama 24 jam

\begin{tabular}{c}
\hline Total $(\mathrm{J})$ \\
\hline Batasan \\
\hline Masing-masing dusun memiliki nilai total, dari nilai total tersebut \\
didapatkan penggolongan dusun dengan ketentuan berikut: \\
- Untuk dusun dengan nilai total $<250$ maka tergolong dusun dengan \\
sistem penyediaan air buruk \\
- Untuk dusun dengan $250<$ nilai total $>500$ tergolong dusun dengan \\
sistem penyediaan air sedang \\
- Untuk dusun dengan nilai total $\geq 500$ tergolong dusun tidak dengan \\
sistem penyediaan air baik \\
\hline \hline
\end{tabular}

Analisis data dilakukan dengan diskriptif. Hasil analisis menggambarkan kepuasan pelanggan PDAM maupun non PDAM, kondisi sarana air bersih eksisting, penilaian sistem penyediaan eksisiting, dan penerapan teknologi yang disesuaikan dengan kondisi masing-masing desa. Penilaian ditinjau dari segi kuantitas, kualitas, dan kontinuitas sumber air tiap-tiap dusun. Indikator penilaian sitem penyediaan eksisting tiap dusun dapat dilihat pada Tabel 2.

\section{HASIL DAN PEMBAHASAN}

\section{A. Desa Metatu}

\section{Sistem Penyediaan Eksisting}

Secara geografis Desa Metatu berjarak $\pm 5 \mathrm{~km}$ dari pusat kantor Kecamatan Benjeng. Sebelah utara berbatasan dengan Desa Punduttrate, sebelah selatan berbatasan dengan Desa Klampok, sebelah timur berbatasan dengan Desa Kadangan, dan sebelah barat berbatasan dengan Desa Jogodalu. Luas wilayahnya $3,99 \mathrm{~km} 2$. Ketika musim penghujan sebagian wilayah terkena dampak banjir. Desa Metatu memiliki 3 dusun diantaranya, Dusun Metatu, Dusun Purworejo, dan Dusun Medangan.

\section{- Dusun Metatu}

Sistem penyediaan air bersih di Dusun Metatu bersumber dari dua air embung yang terletak pada koordinat $07^{\circ} 13^{\prime} 17,6^{\prime \prime}$ S $112^{\circ} 29^{\prime} 58,0^{\prime \prime} \mathrm{E}$ yang dapat dilihat pada Gambar 1 dan $07^{\circ} 13^{\prime} 05,7^{\prime}$ 'S $112^{\circ} 29^{\prime} 55,4^{\prime \prime}$ E yang dapat dilihat pada Gambar 2 .

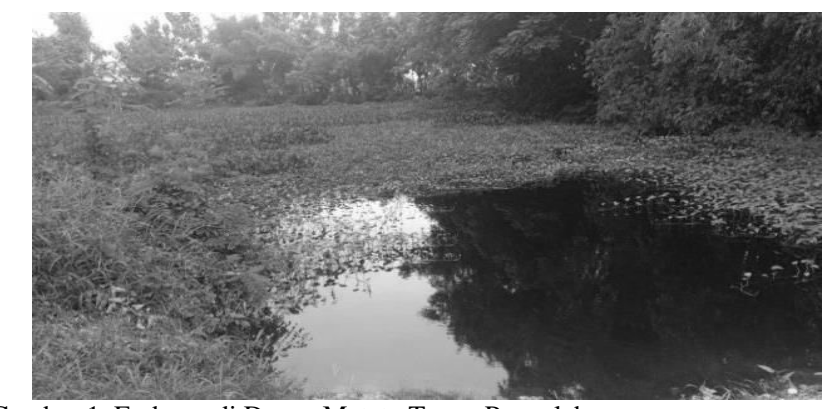

Gambar 1. Embung di Dusun Metatu Tanpa Pengolahan.

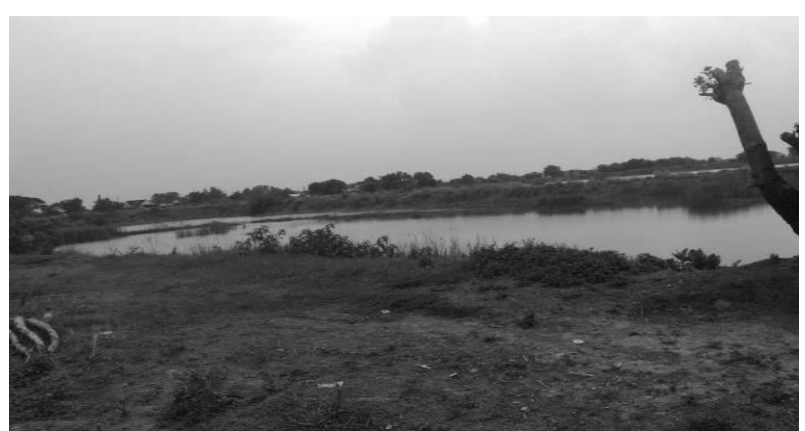

Gambar 2. Embung di Dusun Metatu dengan Pengolahan Filter. (Dokumentasi Penyusun)

Kedalaman embung masing-masing berkisar \pm 3 m dan \pm 7 $\mathrm{m}$ dan ketika musim kemarau tidak mengalami kekeringan kecuali musim kemarau panjang. Kondisi air embung sedikit keruh kehijauan. Masyarakat memanfaatkan air embung untuk mandi, cuci-cuci, dan sebagian untuk memasak. Embung yang satu tanpa adanya pengolahan, sedangkan embung lain disimpan dalam profil tank dengan kapasitas $5300 \mathrm{~L}$ kemudian melewati pengolahan filter pasir sebelum dialirkan ke rumahrumah warga. Penyaluran kerumah warga dengan sistem gravitasi pipa. Hasil air setelah pengolahan tetap keruh. Sistem filter pasir dapat dilihat pada Gambar 3 . 


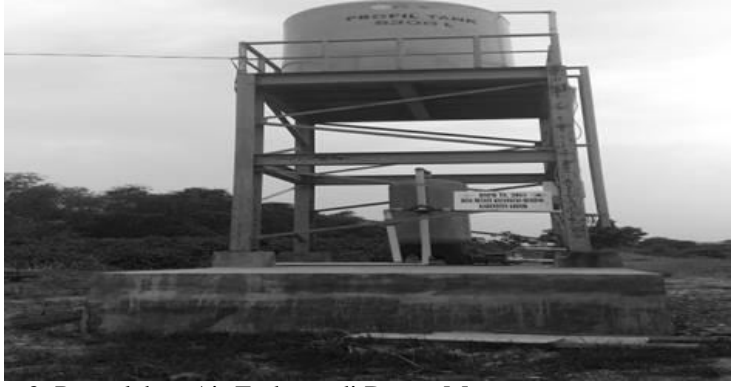

Gambar 3. Pengolahan Air Embung di Dusun Metatu.

- Dusun Purworejo

Masyarakat di Dusun Purworejo menggunakan air embung untuk keperluan mandi dan cuci-cuci. Terdapat sebuah embung dengan kedalaman $\pm 5 \mathrm{~m}$, koordinat $07^{\circ} 12^{\prime} 46,8^{\prime \prime} \mathrm{S}$ dan $112^{\circ} 31^{\prime} 15,1^{\prime \prime}$ E yang dapat dilihat pada Gambar 4 . Kondisi air embung keruh kehijauan dan tidak mengalami kekeringan di musim kemarau kecuali musim kemarau panjang. Ketika musim kemarau panjang masyarakat membeli air tangki kapasitas $5000 \mathrm{~L}$ dengan harga Rp 180.000,- dan disimpan di profil tank depan masing-masing rumah.

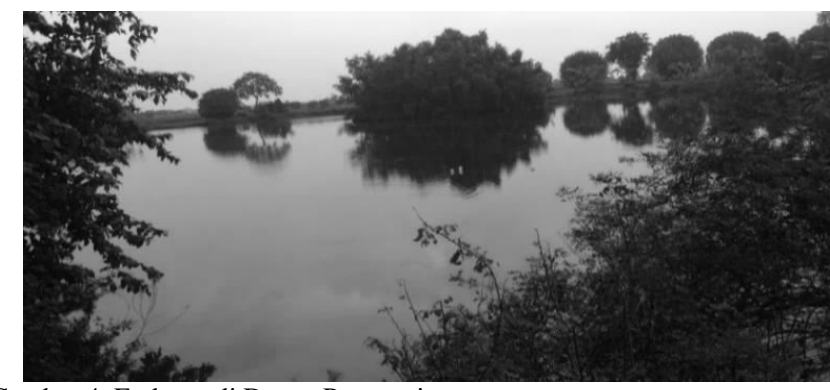

Gambar 4. Embung di Dusun Purworejo.

Cara pengambilan air embung dengan menaikkan air embung, disimpan dalam profil tank kapasitas $5300 \mathrm{~L}$, kemudian dialirkan ke warga secara gravitasi menggunakan pipa seperti pada Gambar 5. Air yang sampai ke warga dalam kondisi masih keruh dan sedikit berbau.

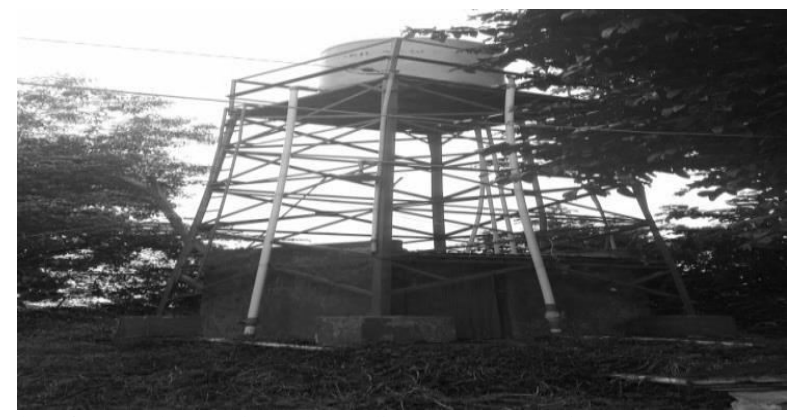

Gambar 5. Penyaluran Air Embung di Dusun Purworejo.

\section{- Dusun Medangan}

Di dusun Medangan terdapat sebuah embung yang biasa digunakan masyarakat untuk keperluan mandi dan cuci-cuci, terletak pada koordinat $07^{\circ} 13^{\prime} 53,2^{\prime \prime} \mathrm{S}$ dan $112^{\circ} 30^{\prime} 01,7^{\prime \prime} \mathrm{E}$ dengan kedalaman $\pm 5 \mathrm{~m}$ yang dapat dilihat pada Gambar 6 . Pengambilan air embung oleh masyarakat secara manual dengan jeriken tanpa adanya pengolahan. Kondisi air embung keruh kehijauan.

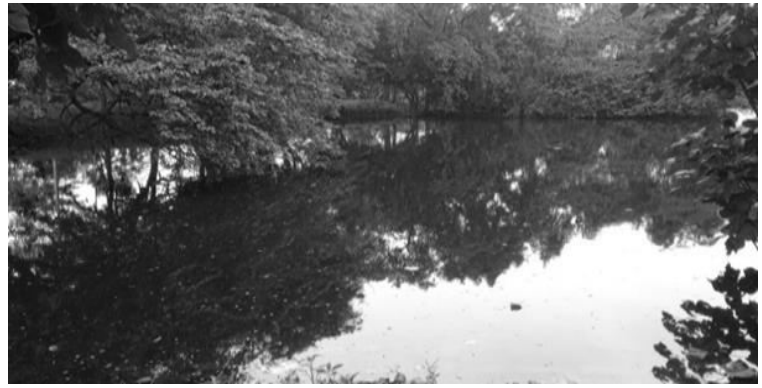

Gambar 6. Embung di Dusun Medangan.

\section{Kebutuhan Air}

Perhitungan proyeksi kebutuhan berada pada rentang tahun 2015 hingga tahun 2030 telah dibahas pada sub bab sebelumnya tentang proyeksi kebutuhan air. Berikut disajikan tabel penyebaran kepadatan penduduk dan kebutuhan air setiap dusun dalam rentang setiap 5 tahun yang dapat dilihat pada Tabel 3 .

Tabel 3.

Kebutuhan Air Desa Metatu

\begin{tabular}{cccccc}
\hline \hline \multirow{2}{*}{ Dusun } & $\begin{array}{c}\% \\
\text { Penyebaran } \\
\text { Kepadatan } \\
\text { Penduduk }\end{array}$ & $\begin{array}{c}\text { Tahun } \\
2015\end{array}$ & $\begin{array}{c}\text { Tahun } \\
2020\end{array}$ & $\begin{array}{c}\text { Tahun } \\
2025\end{array}$ & Tahun \\
& 52 & 0,35 & 1,87 & 3,49 & 4,65 \\
\hline Metatu & 19 & 0,13 & 0,68 & 1,28 & 1,70 \\
Purworejo & 29 & 0,19 & 1,04 & 1,95 & 2,59 \\
Medangan & 100 & 0,67 & 3,59 & 6,72 & 8,94 \\
Total & & & &
\end{tabular}

3. Analisis Penilaian Penyediaan Eksisting

Penilaian dari segi kuantitas, kualitas, dan kontinuitas. Desa Metatu memanfaatkan sumber air dari air embung yang dapat dilihat kuantitas masing-masing embung pada Tabel 4.

Tabel 4.

Kuantitas Embung Desa Metatu

\begin{tabular}{cccc}
\hline Dusun & $\begin{array}{c}\text { Kedalaman } \\
\text { Embung Rata- } \\
\text { Rata (m) } \\
(\mathrm{A})\end{array}$ & $\begin{array}{c}\text { Luas Embung } \\
\left(\mathrm{m}^{2}\right) \\
(\mathrm{B})\end{array}$ & $\begin{array}{c}\text { Volume } \\
\text { Embung } \\
\text { Rata-Rata } \\
\left(\mathrm{m}^{3}\right) \\
(\mathrm{C})=\mathrm{AxB}\end{array}$ \\
\hline Matatu 1 & 3 & $2.404,84$ & $7.214,52$ \\
Metatu 2 & 7 & $9.773,66$ & $68.415,62$ \\
Purworejo & 5 & $5.435,37$ & $27.176,85$ \\
Medangan & 5 & $3.081,56$ & $15.407,80$ \\
\hline \hline
\end{tabular}

Sedangkan dari kualitas dapat dilihat kualitas embung pada kategori wilayah banjir di mana embung di Dusun Purworejo dan Dusun Medangan tidak melewati sitem pengolahan dan pengambilan manual sehingga secara fisik memiliki tingkat warna yang cukup tinggi, secara kimia memiliki kesadahan dan zat organik yang cukup tinggi, sedangkan secara mikrobiologi total koliform yang banyak. Untuk Dusun Metatu yang melewati filter, memiliki kualitas air warna dan tingkat kekeruhan yang tinggi, secara kimia mengandung amonia, besi, mangan, zat organik yang tinggi, serta total kolirom yang banyak. Hal ini disebabkan operasi dan pemeliharaan filter yang kurang tepat. Dari segi kontinuitas dari embung di Desa Metatu dapat dilihat pada Tabel 5. 
Tabel 5.

Sifat Kontinuitas Embung di Desa Metatu

\begin{tabular}{|c|c|c|c|c|}
\hline Dusun & $\begin{array}{c}\text { Volume } \\
\text { Embung } \\
\text { Rata- } \\
\text { Rata }\left(\mathrm{m}^{3}\right) \\
\text { (A) }\end{array}$ & $\begin{array}{c}\text { Kebutuhan } \\
\text { Air Tahun } \\
2030 \text { selama } \\
\text { musim } \\
\text { kemarau } \\
\left(\mathrm{m}^{3} / 180 \mathrm{hr}\right) \\
\text { (B) }\end{array}$ & $\begin{array}{l}\text { Sisa }\left(\mathrm{m}^{3}\right) \\
(\mathrm{C})=\mathrm{A}-\mathrm{B}\end{array}$ & Keterangan \\
\hline $\begin{array}{l}\text { Metatu } 1 \\
\text { Metatu } 2\end{array}$ & $\begin{array}{c}7.214,52 \\
68.415,62\end{array}$ & $72.316,8$ & 3.313 & Memenuhi \\
\hline Purworejo & $27.176,85$ & $26.438,4$ & 738 & Memenuhi \\
\hline Medangan & $15.407,80$ & $40.279,68$ & -24.872 & $\begin{array}{c}\text { Tidak } \\
\text { memenuhi }\end{array}$ \\
\hline
\end{tabular}

Kemudian dilakukan penilaian sesuai ketentuan yang telah dijelaskan pada metodologi, sehingga sistem penyediaan air di Desa Metatu dapat dinilai seperti pada Tabel 6.

Tabel 6.

Penilaian Sistem Penyediaan Eksisting di Desa Metatu

\begin{tabular}{ccccc}
\hline \hline \multicolumn{5}{c}{ Dusun Metatu } \\
& Bobot (A) & Skor (B) & $\begin{array}{c}\text { Nilai (C) } \\
=\text { AxB }\end{array}$ & Total \\
\hline Kuantitas & 40 & 5 & 200 & \\
Kualitas & 20 & 1 & 20 & 420 \\
Kontinuitas & 40 & 5 & 200 & \\
& \multicolumn{5}{c}{ Dusun Purworejo } \\
& Bobot (A) & Skor (B) & Nilai (C) & Total \\
Kuantitas & 40 & 3 & 120 & \\
Kualitas & 20 & 1 & 20 & 340 \\
Kontinuitas & 40 & 5 & 200 & \\
& \multicolumn{5}{c}{ Dusun Medangan } & Nilai (C) & Total \\
& Bobot (A) & Skor (B) & $=$ AxB & \\
Kuantitas & 40 & 1 & 40 & 100 \\
Kualitas & 20 & 1 & 20 & \\
Kontinuitas & 40 & 1 & 40 &
\end{tabular}

Tabel 7.

Alternatif Penyediaan Air di Desa Metatu

\begin{tabular}{cc}
\hline \hline Dusun & Alternatif Penyediaan Air Bersih \\
\hline Metatu & Pengolahan air embung \\
Purworejo & Pengolahan air embung \\
Medangan & Mobil tangki air, PAH \\
\hline \hline
\end{tabular}

Tabel 8.

Embung di Desa Kalipadang

\begin{tabular}{llll}
\hline \hline Karakteristik & Dusun Ploso & Dusun Kalisari \\
\hline Koordinat & $07^{\circ} 15^{\prime} 45,5^{\prime}, \mathrm{S}$ & $07^{\circ} 15^{\prime} 59,8^{\prime \prime} \mathrm{S}$ \\
Kedalaman & $112^{\circ} 28^{\prime} 06,6^{\prime} \mathrm{E}$ & $112^{\circ} 27^{\prime} 37,0^{\prime \prime} \mathrm{E}$ \\
Kondisi Embung & $\pm 4 \mathrm{~m}$ & $\pm 3 \mathrm{~m}$ & \\
Kondisi ketika & kehijauan keruh & Keruh, banyak \\
musim kemarau & Berkurang, tidak & tumbuhan liar \\
Kegunaan & sampai kering & Kering \\
Pengambilan & Mandi dan mencuci & Mandi dan mencuci \\
Kengolahan & Konvensional & Konvensional \\
dengan jeriken & dengan jeriken \\
\hline \hline
\end{tabular}

Dari nilai total yang didapat dapat dilihat bahwa Dusun Metatu dan Purworejo termasuk dusun dengan sistem penyediaan air cukup, sedangkan Dusun Medangan tergolong sistem penyediaan buruk.

4. Penerapan Teknologi Penyediaan Air Bersih

Pengaplikasian teknologi yang sesuai berdasarkan karakteristik masing-masing dusun dapat dilihat pada Tabel 7.

\section{B. Desa Kalipadang}

\section{Sistem Penyediaan Eksiting}

Desa Kalipadang memiliki luas wilayah 308 ha, didominasi areal persawahan 205,10 ha. Memiliki 5 dusun, yaitu Dusun Kalipadang, Dusun Gesing, Dusun Kalimoro, Dusun Kalisari, dan Dusun Ploso. Dari kelima dusun, dua dusun memakai sumber air embung yaitu Dusun Ploso dan Dusun Kalisari seperti pada Gambar 7. Sedangkan tiga dusun yang lain memanfaatkan sumber air dari sumur gali dan sumur bor. Berikut adalah data embung di Desa Kalipadang. Perbedaan kedua embung di Desa Kalipadang dapat dilihat pada Tabel 8.

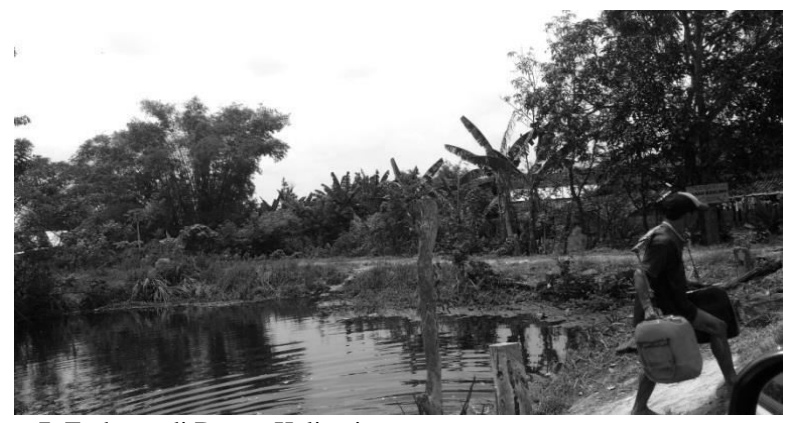

Gambar 7. Embung di Dusun Kalisari.

Sedangkan dusun Kalimoro, Dusun Gesing dan Dusun Kalipadang memanfaatkan air sumur baik sumur gali maupun sumur bor. Kedalaman untuk sumur gali $\pm 7 \mathrm{~m}$ dengan kualitas air jernih dan tawar. Kedalaman sumur bor $\pm 55 \mathrm{~m}$ namun kualitas air asin dan sedikit kuning. Diambil salah satu contoh sumur gali milik warga di Dusun Kalimoro dengan koordinat $07^{\circ} 15^{\prime} 46,6^{\prime \prime}$ S $112^{\circ} 28^{\prime} 29,4^{\prime \prime}$ E seperti pada Gambar 8.

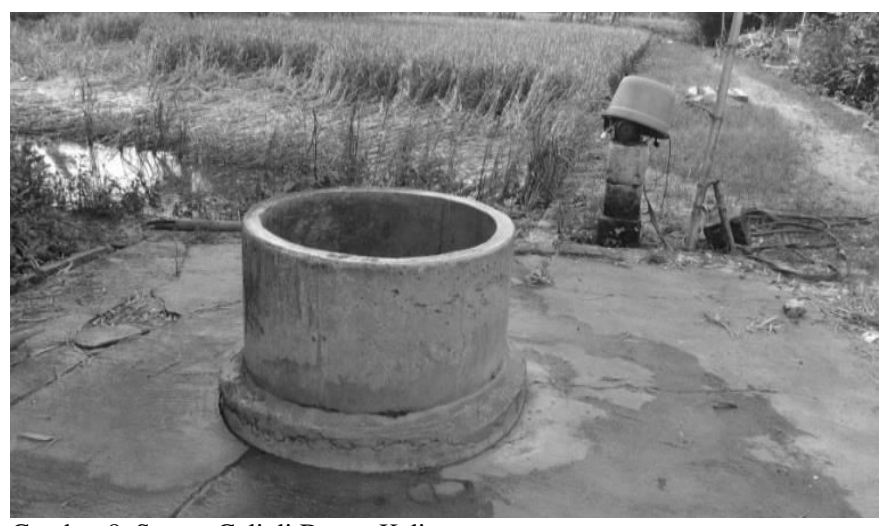

Gambar 8. Sumur Gali di Dusun Kalimoro.

\section{Kebutuhan Air}

Perhitungan proyeksi kebutuhan berada pada rentang tahun 2015 hingga tahun 2030 telah dibahas pada sub bab sebelumnya tentang proyeksi kebutuhan air. Berikut disajikan tabel penyebaran kepadatan penduduk dan kebutuhan air 
setiap dusun dalam rentang setiap 5 tahun yang dapat dilihat pada Tabel 9 .

Tabel 9.

Kebutuhan Air Desa Kalipadang

\begin{tabular}{llllll}
\hline \hline \multirow{5}{*}{ Dusun } & \% & \multicolumn{2}{l}{ Kebutuhan Air $(\mathrm{l} / \mathrm{dt})$} & \\
& $\begin{array}{l}\text { Penyebaran } \\
\text { Kepadatan }\end{array}$ & Tahun & Tahun & Tahun & Tahun \\
& Penduduk & 2015 & 2020 & 2025 & 2030 \\
\hline Kalipadang & 37 & 1,65 & 1,91 & 2,24 & 2,40 \\
Gesing & 18 & 0,80 & 0,93 & 1,09 & 1,17 \\
Kalimoro & 7 & 0,31 & 0,36 & 0,42 & 0,45 \\
Kalisari & 15 & 0,67 & 0,77 & 0,91 & 0,97 \\
Ploso & 22 & 0,98 & 1,14 & 1,33 & 1,43 \\
Total & 100 & 4,45 & 5,16 & 6,07 & 6,50 \\
\hline \hline
\end{tabular}

3. Analisis Penilaian Penyediaan Eksisting

Penilaian dari segi kuantitas, kualitas, dan kontinuitas. Desa Kalipadang memanfaatkan sumber air dari air embung yang dapat dilihat kuantitas masing-masing embung pada Tabel 10.

Tabel 10 .

Kuantitas Embung Desa Kalipadang

\begin{tabular}{cccc}
\hline \hline Kedalaman & $\begin{array}{c}\text { Luas Embung } \\
\text { Embung Rata- } \\
\text { Rata }(\mathrm{m})\end{array}$ & $\begin{array}{c}\text { Volume } \\
(\mathrm{m})\end{array}$ & $\begin{array}{c}\text { Embung Rata- } \\
\text { Rata }\left(\mathrm{m}^{3}\right) \\
(\mathrm{C})=\text { AxB }\end{array}$ \\
\hline Kalipadang & - & $(\mathrm{B})$ & - \\
Gesing & - & - & - \\
Kalimoro & - & - & - \\
Kalisari & 3 & - & $7.256,46$ \\
Ploso & 4 & $2.418,82$ & $5.453,60$ \\
\hline \hline
\end{tabular}

Sedangkan dari kualitas dapat dilihat pada kategori wilayah sumur dengan embung kering ketika musim kemarau di mana diambil 2 sampel air embung di Dusun Kalisari dan Dusun Ploso, diambil 2 sampel air sumur, untuk sumur 1 yaitu sumur gali dan sumur 2 yaitu sumur bor di Dusun Kalimoro. Semua embung di Desa Kalipang tidak melewati sitem pengolahan dan pengambilan secara konvensional sehingga secara fisik memiliki tingkat warna yang cukup tinggi, secara kimia mengandung mangan dan zat organik yang cukup tinggi, sedangkan secara mikrobiologi total koliform yang jauh melebihi baku mutu. Sedangkan kualitas air sumur gali maupun air sumur bor di Dusun Kalimoro tidak jauh berbeda dengan kualitas air embung, namun kualitas air sumur gali lebih baik dibandingkan dengan sumur bor, karena kandungan mangan dari air sumur gali terbilang kecil dan secara fisik memiliki tingkat warna yang kecil atau lebih jernih. Dari segi kontinuitas dari sumber air di Desa Kalipadang dapat dilihat pada Tabel 11 .

Kemudian dilakukan penilaian sesuai ketentuan indikator yang telah dijelaskan pada metodologi, sehingga sistem penyediaan air di Desa Kalipadang dapat dinilai seperti pada Tabel 12.

Tabel 11.

Sifat Kontinuitas Embung di Desa Kalipadang

\begin{tabular}{ccccc}
\hline \hline \multirow{5}{*}{ Dusun } & $\begin{array}{c}\text { Volume } \\
\text { Embung } \\
\text { Rata- } \\
\text { Rata }\left(\mathrm{m}^{3}\right) \\
(\mathrm{A})\end{array}$ & $\begin{array}{c}\text { Kebutuhan Air } \\
\text { Tahun 2030 } \\
\text { selama musim } \\
\text { kemarau } \\
\left(\mathrm{m}^{3} / 180 \mathrm{hr}\right)(\mathrm{B})\end{array}$ & $\begin{array}{c}\text { Sisa } \\
\left(\mathrm{m}^{3}\right)\end{array}$ & Keterangan \\
$(\mathrm{C})=\mathrm{A}-$ & \\
\hline Kalipadang & - & $37.324,8$ & - & Tidak terpenuhi \\
Gesing & - & $18.195,84$ & - & Tidak terpenuhi \\
Kalimoro & - & $6.998,4$ & - & Terpenuhi oleh \\
\hline \hline
\end{tabular}

\begin{tabular}{ccccc}
\hline \hline & & & & sumber air \\
tanah(sumur) \\
Kalisari & $7.256,46$ & $15.085,44$ & -7.829 & Tidak terpenuhi \\
Ploso & $5.453,60$ & $22.239,36$ & - & Tidak terpenuhi \\
\hline \hline
\end{tabular}

Dari nilai total yang didapat Desa Kalipadang termasuk Desa dengan sistem penyediaan buruk untuk Dusun Kalipadang, Gesing, Kalisari, dan Ploso. Sedangkan Dusun Kalimoro memiliki sistem penyediaan sedang.

4. Penerapan Teknologi Penyediaan Air Bersih

Pengaplikasian teknologi yang sesuai berdasarkan karakteristik masing-masing dusun dapat dilihat pada Tabel 13.

Tabel 12.

Penilaian Sistem Penyediaan Eksisting di Desa Kalipadang

\begin{tabular}{|c|c|c|c|c|}
\hline \multicolumn{5}{|c|}{ Dusun Kalipadang } \\
\hline & Bobot (A) & Skor (B) & $\begin{array}{c}\text { Nilai }(\mathrm{C}) \\
=\mathrm{AxB}\end{array}$ & Total \\
\hline Kuantitas & 40 & 1 & 40 & \\
\hline Kualitas & 20 & 1 & 20 & 100 \\
\hline Kontinuitas & 40 & 1 & 40 & \\
\hline \multicolumn{5}{|c|}{ Dusun Gesing } \\
\hline & Bobot (A) & Skor (B) & $\begin{array}{l}\text { Nilai }(\mathrm{C}) \\
=\mathrm{AxB}\end{array}$ & Total \\
\hline Kuantitas & 40 & 1 & 40 & \\
\hline Kualitas & 20 & 1 & 20 & 100 \\
\hline Kontinuitas & 40 & 1 & 40 & \\
\hline \multicolumn{5}{|c|}{ Dusun Kalimoro } \\
\hline & Bobot (A) & Skor (B) & $\begin{array}{l}\text { Nilai }(\mathrm{C}) \\
=\mathrm{AxB}\end{array}$ & Total \\
\hline Kuantitas & 40 & 3 & 120 & \\
\hline Kualitas & 20 & 1 & 20 & 340 \\
\hline Kontinuitas & 40 & 5 & 200 & \\
\hline \multicolumn{5}{|c|}{ Dusun Kalisari } \\
\hline & Bobot (A) & Skor (B) & $\begin{array}{c}\text { Nilai (C) } \\
=A x B\end{array}$ & Total \\
\hline Kuantitas & 40 & 1 & 40 & \\
\hline Kualitas & 20 & 1 & 20 & 100 \\
\hline Kontinuitas & 40 & 1 & 40 & \\
\hline \multicolumn{5}{|c|}{ Dusun Ploso } \\
\hline & Bobot (A) & Skor (B) & $\begin{array}{l}\text { Nilai (C) } \\
=A x B\end{array}$ & Total \\
\hline Kuantitas & 40 & 1 & 40 & \\
\hline Kualitas & 20 & 1 & 20 & 100 \\
\hline Kontinuitas & 40 & 1 & 40 & \\
\hline
\end{tabular}

Tabel 13.

Alternatif Penyediaan Air di Desa Kalipadang

\begin{tabular}{cc}
\hline \hline Dusun & Alternatif Penyediaan Air Bersih \\
\hline Kalipadang & Tandon hidran umum \\
Gesing & Tandon hidran umum \\
Kalimoro & Pengolahan air sumur skala rumah tangga \\
Kalisari & Tandon hidran umum \\
Ploso & Tandon hidran umum \\
\hline \hline
\end{tabular}

\section{KESIMPULAN}

Desa Metatu dan Desa Kalipadang memanfaatkan sumber air dari air embung dan air tanah (sumur). Terdapat pengolahan air embung sederhana dengan filter pasir di Desa Metatu, namun kualitas hasil air tidak bagus dikarenakan filter tidak bekerja dengan baik. Desa Metatu termasuk desa sistem penyediaan sedang karena kuantitas dan kontinuitas sumber air cukup memenuhi kebutuhan penduduk. Sedangkan Desa Kalipadang termasuk desa sistem penyediaan buruk, karena 
kuantitas sumber air belum mampu memebuhi kebutuhan air penduduk. Tenologi yang sesuai untuk Desa Metatu adalah pengolahan air embung, mobil tangki air, dan PAH. Sedangkan untuk Desa Kalipadang sesuai diterapkan teknologi tandon hindran umum dan pengolahan air sumur skala rumah tangga.

\section{UCAPAN TERIMA KASIH}

Penulis mengucapkan terimakasih kepada Altwater Project yang telah mendanai penelitian ini.

\section{DAFTAR PUSTAKA}

[1] N. I. Said and S. Yudo, "Masalah dan strategi penyediaan air bersih di Indonesia," Teknol. pengelolaan air minum Teor. dan pengalaman Prakt., pp. 80-106, 2008.

[2] Badan Pusat Statistik, "Kecamatan Benjeng Dalam Angka 2016," Gresik, 2016.

[3] BAPPEDA Gresik, "Rencana Kerja Pembangunan Daerah Kabupaten Gresik Tahun 2015,” Gresik, 2015. 